\title{
Analysis of Student Satisfaction Against Teacher Services at SMA Sabilurosyad Malang
}

\author{
Sarah Emmanuel Haryono*, Henni Anggraini \\ Department of Early Childhood Education \\ Kanjuruhan University \\ Malang, Indonesia \\ *sarah.emmanuel@unikama.ac.id, hennianggraini@unikama.ac.id
}

\begin{abstract}
The quality of school services greatly affects the credibility of educational institutions. The success of a service in achieving its goals is very dependent on the student satisfaction with school services. The purpose of this study was to measure student satisfaction with teacher services at SMA Sabilul Rosyad Malang. The research method is survey research design by using a determination instrument in the form of a student satisfaction. The subjects in this study amounted to 30 students. The results of this study illustrate that the teacher's ability to describe students' abilities has the highest percentage level of approval with a score of $51.72 \%$. The teacher's ability in implementing learning has a high enough percentage with an agreement score of $55.17 \%$.The teacher's understanding of the student's needs received a high enough level of agreement with a score of $41.38 \%$. The teacher's ability to handle and respond to student conditions both had a high percentage of approval with a score of $51.72 \%$. Based on the results of the analysis above, it can be concluded that the quality of services at the SMA Sabilul Rosyad Malang institution still has to be improved, so that the educational goals within the institution can be achieved optimally.
\end{abstract}

\section{Keywords—student satisfaction, teacher services}

\section{INTRODUCTION}

In the era of globalization that is increasingly advanced, it will be easier for people to find educational institutions that are spread across all regions, both formal and non-formal. To meet the needs of society to develop self-potential and hone skills to face challenges in the era of globalization. In the era of globalization, everyone is required to develop their potential and skills to be able to survive and compete in all areas of life.

The progress of the times and the intense competition, greatly affects the world of technology, and does not rule out the world of education. School as an educational institution must demonstrate a quality that is able to provide scientific / scientific knowledge and life skills for its students. Schools are expected to provide superior educational services.

Institutions must be able to improve the quality of services provided to each student. the services provided must be able to meet the needs of students. The definition of quality or quality is closely related to customer satisfaction. This is as expressed by Ishikawa [1] which states that quality is satisfaction. Thus, a product can be said of quality for someone when the product can meet their needs. Meanwhile, people will experience satisfaction when their needs are met.

Formal / school education has a role to provide the ability to develop various things, such as concepts, principles, creativity, responsibility, and skills that are needed by students through the education process in schools. Therefore, schools must guarantee the quality to be able to meet the needs of these students because students will feel satisfaction if their needs are met, and will feel disappointed if their needs are not met. The educational process will take place effectively if there is conformity with student needs [2].

Schools are expected to provide good service quality. The quality of services in an educational institution greatly affects the outcomes produced by educational institutions. Service quality is an interesting and meaningful study to be studied more specifically, in order to help develop the potential of students to the maximum. The quality of service is important because it will have a direct impact on the image of educational institutions.

The quality of service in an educational institution greatly affects the outcomes produced by educational institutions. Service quality is an interesting and meaningful study to be studied more specifically, in order to help develop the potential of students to the maximum. The quality of service is important because it will have a direct impact on the image of educational institutions.

Good service quality will be an advantage for educational institutions. Feigenbaum [3], states that quality is full customer satisfaction. A quality product if it can provide full satisfaction to consumers, namely in accordance with what consumers expect for a product / service. Garvin and Davis [3], state that quality is a dynamic condition related to products, people / workforce, processes and tasks and the environment that meets or exceeds customer or consumer expectations.

Service quality can be defined as something that satisfies and exceeds customer wants and needs. Crosby [4] defines quality as "conformance to requirements" and Juran \& Gryna 
[5] defines it as "fitness for use". TQM (Total Quality Management) is an extension and development of quality assurance. TQM (Total Quality Management) is about creating a quality culture, which.

Encourages all staff members to satisfy customers. Zazin [6] adds that the concept of Total Quality Management must meet predetermined specifications. Operationally, quality is determined by two factors, namely the fulfilment of predetermined specifications or called quality in fact and the fulfilment of the expected specifications according to the demands and needs of service users or called quality in perception.

Quality standards are actually measured by the quality of production according to the criteria according to specifications, suitable for the purpose of manufacture and use, without defects (zero defects), and always good from the start (right first time and every time). Quality in perception is measured by customer or user satisfaction, increased interest, expectations and customer satisfaction. Quality or quality has the following elements: first, includes efforts to meet or exceed customer expectations. Second, includes products, services, people, processes and the environment. Third, it is a condition that is always changing. Education is a service or service and not the production of goods. The only service performance indicator is customer satisfaction, the performance of education quality can be measured by the level of customer satisfaction.

From some of the above meanings, it can be concluded that quality is a continuous improvement effort made by an organization so that goals can be achieved by involving all components in the organization as an effort to meet customer needs and satisfaction.

Measuring service quality can be done by paying attention to the 5 dimensions of service quality expressed by Parasuraman et al. [7], namely: reliability, assurance, tangibles (physical evidence), empathy (empathy), responsiveness (responsiveness). Service quality is related to the concept of perception and expectation [7]. Customer perceptions of service quality are based on a comparison between their expectations before the service is provided with empirical / actual service experiences. Service will be considered very good, if the perception exceeds expectations; it will be deemed good or adequate, if it only equals hope; service will be classified as bad, poor or lacking, if it does not meet them [3].

Quality resources in education, for example good building facilities, outstanding teachers, high moral values, satisfactory examination results, specialization or vocational, encouragement from parents, business and local communities, abundant resources, application of the latest technology, good leadership and effective, attention to students and students, adequate curriculum, or also a combination of these factors. Organizations that take the achievement of quality seriously, understand that most quality secrets are rooted in listening to and responding sympathetically to the needs and wants of customers and clients. Achieving quality involves having to do everything well, and an institution must position customers appropriately and proportionally so that quality can be achieved [8].

The quality of services in an educational institution provided by teachers is felt by students. The satisfaction value felt by students can be a benchmark in assessing the quality of an educational service that is carried out within an educational institution / institution, in this study the researcher aims to analyse the quality of services provided by teachers based on the perceptions of students at SMA Sabilurosyad.

\section{METHODS}

Methodology in this research are used survey research design. Kraemer [9] identified three distinguishing characteristics of survey research. First, survey research is used to quantitatively describe specific aspects of a given population. These aspects often involve examining the relationships among variables. Second, the data required for survey research are collected from people and are, therefore, subjective. Finally, survey research uses a selected portion of the population from which the findings can later be generalized back to the population. In survey research, independent and dependent variables are used to define the scope of study, but cannot be explicitly controlled by the researcher. Before conducting the survey, the researcher must predicate a model that identifies the expected relationships among these variables. The survey is then constructed to test this model against observations of the phenomena.

In this study, the researcher used the phenomena of student satisfaction about teacher service at SMA Sabilul Rosyad. SMA Sabilul Rosyad is a one of boarding school in Malang. Through this research, the researcher wants to describe student satisfaction, which is seen from several things, which include the ability of teachers to provide academic services, personal services, the ability of teachers to meet student needs (physical and psychological), and the availability of learning infrastructure in schools.

The sampling technique used in this study was random stratified random sampling. Stratified random sampling is a sampling technique with attention to a level (strata) in population elements. Population elements are divided into several levels (stratification) based on the characters attached to them. In stratified random sampling, population elements are grouped at certain levels with the aim of sampling to be evenly distributed at all levels and the sample representing the character of all heterogeneous population elements [10]. The researcher randomly took student representatives from each level. Researchers used 10 students from class X, 10 students from class XI, and 10 students from class XII. The number of samples in this study were 30 students.

The instrument used in this study was a service quality questionnaire, which was developed based on the theory of service quality dimensions expressed by Parasuraman et al. [7], namely: Reliability, Assurance, Tangibles (physical evidence), empathy (empathy), responsiveness (responsiveness). The questionnaire developed by the researcher provides 5 answer 
choices: $\mathrm{TS}=$ verry disagree; $\mathrm{KS}=$ disagree; $\mathrm{S}=$ agree; $\mathrm{SS}=$ very agree; SSS = very much agree. The subject is asked to provide the answer that best suits the subject's condition.

\section{RESULTS AND DISCUSSION}

The results showed that the teacher's ability to describe students' abilities had the highest percentage level of approval with a score of $51.72 \%$. The teacher's ability in implementing learning has a high enough percentage with an agreement score of $55.17 \%$. The cleanliness of the school environment has a fairly high percentage of approval with a score of $55.17 \%$. The teacher's understanding of the student's needs received a high enough level of agreement with a score of $41.38 \%$. The ability of teachers in handling and responding to student conditions has a high percentage of approval with a score of $51.72 \%$.

The services provided in accordance with the student's condition still have to be improved because the score is $6.90 \%$ which states that they strongly agree. The improvement of comfortable communication between teachers and students must continue to be developed considering that there are still students who feel uncomfortable when communicating with teachers about private matters, this is indicated by a score of $3.4 \%$ of students disagree and $6.90 \%$ of students who are verystrongly agree. The lack of availability of places to do assignments that are comfortable for students is shown by the percentage of $13.79 \%$ of students disagreeing, $15.72 \%$ of students disagreeing, $17.24 \%$ of students agreeing, $6.68 \%$ of students strongly agreeing, and $10.34 \%$ of students strongly Strongly agree. the suitability of the services provided with the needs of students must be continuously improved which is illustrated by the percentage of $3.45 \%$ of students disagree, $27.59 \%$ of students disagree, $24.24 \%$ of students agree, $24.14 \%$ of students strongly agree, and $20.69 \%$ of students strongly agree. The teacher's ability to help meet the needs of students must continue to be improved with an overview of the percentage of $3.45 \%$ of students disagreeing, $17.24 \%$ of students disagreeing, $34.48 \%$ of students agreeing, and $24.14 \%$ of students strongly agreeing, $20.69 \%$ of students totally agree.

Perceived service quality can be described as customer satisfaction with how well a service meets their expectations [11-16]. When service delivery expectations are not met, institutions can run into potential problems. A possible scenario is that the agency does not provide services that meet customer expectations [17]. In the world of education, it can be interpreted that there is an assessment of the quality of educational services that is reviewed based on the expectations and perceptions of students and the services provided by schools, which causes customer dissatisfaction in relation to the level of service quality. Thus, dissatisfaction occurs because of a disconfirmation of expectations. As a basis for quality and service satisfaction is based on disconfirmation theory [18].

Based on research conducted by Prentice \& Christopher [3], service satisfaction in the world of education should be reviewed from a student's perspective, so that educational institutions or agencies get a picture of the quality of services provided to students and improve educational services in the future.

\section{CONCLUSION}

Based on the results and discussion above, it can be concluded as follows :

- The teacher is quite capable of understanding and explaining the students' abilities, but the teacher still has to understand more specifically,

- The teacher shows concern for the needs of students,

- The teacher is able to carry out learning that meets the needs of students,

- The teacher is able to provide comfort when communicating with students,

- The teacher is able to provide consistent treatment to students,

- The school provides adequate infrastructure and is still in the renovation stage to support student needs,

- Given by the teacher is sufficient in accordance with the needs of students,

- Giving attention to students is carried out quite well, through giving time to communicate with students intensively, so that it can provide an overview of the conditions and needs of students,

- The form of teacher service is sufficient to provide response to students. the teacher tries to respond to the student's condition.

\section{ACKNOWLEDGMENT}

The author would like to thank Kanjuruhan University Malang for supporting the author in conducting this research.

\section{REFERENCES}

[1] A. Komariah and C. Triana, Visionary Leadership: Menuju Sekolah Efektif, Jakarta: Bumi Aksara, 2005.

[2] M. Surya, Psikologi Pembelajaran dan Pengajaran, Bandung, 2004

[3] Prentice and Christopher, "Education Service Quality, Value and Satisfaction on Student Customer Intentions and Behaviour," Journal of education, 2018

[4] P. Crosby, Crosby talks quality, The TQM Magazine, 1989.

[5] J.M. Juran, "Juran on leadership for quality," Simon and Schuster, 2003.

[6] N. Zazin, Gerakan menata Mutu Pendidikan, Teori dan Aplikasi, Jakarta: Ar- Ruzz Media, 2011.

[7] A. Parasuraman, V.A. Zeithaml, L.L. and Berry, "Reassessment of expectations as a comparison standard in measuring service quality: implications for further research," Journal of Marketing, vol. 58, no. 1, pp. 111-124, 1994.

[8] E. Sallis, Total Quality Management in Education: Manajemen Mutu Terpadu Pendidikan, Jogjakarta: IrCisod, 2010. 
[9] K.L. Kraemer, The information systems research challenge (vol. III) survey research methods, Harvard University Graduate School of Business Administration, 1991.

[10] S.B. Neuman and D.K. Dickinson, Handbook of early literacy research, 2003

[11] S.W.Kelley, J.H. Donnelly, and S.J. Skinner, "Customer participation in service production and delivery," Journal of Retailing, vol. 66, no. 3, pp. 315-335, 1990.

[12] F.M. Hill, "Managing service quality in higher education: the role of the student as primary consumer," Quality Assurance in Education, vol. 3, no. 3, pp. 10-21, 1995.

[13] M. Sirvanci, "Are students the true customers of higher education?," Quality Progess, vol. 29, no. 10, pp. 40-45, 1996.
[14] J.E. Swan, M.R. Bowers, and R. Grover, "Customer involvement in the selection of service specifications," Journal of Services Marketing, vol. 16 , no. 1 , pp. 88-103, 2002.

[15] C. Munteanu, C. Ceobanu, C. Bobalca, and O. Anton, "An analysis of customer satisfaction in a higher education context," International Journal of Public Sector Management, vol. 23, no. 2, pp. 124-140, 2010.

[16] E. Mark, "Student satisfaction and the customer focus in higher education," Journal of Higher Education Policy and Management, vol. 35, no. 1, pp. 2-10, 2013.

[17] V.A. Zeithaml, M.J. Bitner, and D.D. Gremler, Services marketing: Integrating customer focus across the firm, New York: McGraw-Hill, 2006.

[18] D. Lacobucci, K.A. Grayson, and A.L. Ostrom, "The calculus of service quality and customer satisfaction: Theoretical and empirical differentiation and integration," Swartz, T, 1994 